\title{
Modern historical epistemology through the prism of Paul Ricoeur' transactions
}

\author{
Natalia Trubnikova \\ Tomsk Polytechnic University, 634050 Lenina str., 30, Tomsk, Russia
}

\begin{abstract}
In this article it is carried out the contribution of Paul Ricoeur, the leading theorist of modern humanitarian knowledge, in the elaboration of the modern historical epistemology problems. His diverse works affect all sense fields of history and historical perception. The article shows the place of Paul Ricoeur as a primary guide of philosophical hermeneutic tradition achievements in the sphere of historical research, moreover, as a thinker, who gives a principal possibility to surmount divisions of different historiographical trends and find a methodological consensus in regard to basic orientations of historical scholarship. On the basis of his works the dialectic of a historical objectivity and a personal subjectivity of historian, the interoperability issues of history and historical memory are traced. At the same time this paper touches principals dichotomies, basic for the Paul Ricoeur's considerations, such as fiction and historical narration, structure and event, history and truth, memory and imagination, scientism and art of interpretation, human action and social constraint. The contents of a current debate on the theory of history, based on the development of the Ricoeur's "defatalisation" of history concept and utopian future vision are shown.
\end{abstract}

\section{Introduction}

Paul Ricoeur is the central figure of the French historical epistemology. According to the Antoine Pro's quotation, he is the only philosopher, "whom historians can read without a sense of what he says is from another planet" [1]. Long before the researcher of a historical writing poetics Jacques Rancière urged historians to come to terms with their object, and not to yield to the sirens, who are constantly calling them to euthanasia [2], as far back as 1950s. Ricoeur explained that historians were able to form a consistent picture of their craft and uphold their legitimacy by own resources. It becomes possible in case if they reject the prospect of historiographical operation separating to "scientistic" and "subjectivist" direction because the historian always has to balance between the relative objectivity and subjectivity, this "contract of truth" has not changed since the time of Herodotus and Thucydides. Historians began to listen to Ricoeur's arguments only from the second half of the 1990s. In the twenty-first century the scholarship of Ricoeur as the most famous conductor of hermeneutic tradition in historical science, becomes a true foundation of a modern historical epistemology.

\section{Materials and methods}

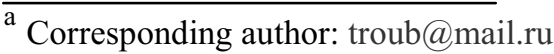

The study assumed the use of the traditional instruments of historiographical scholarship: general logical (analysis, synthesis, induction, abstraction, idealization, analogy, modelling), general historical (genetic, comparative, typological, problem-chronological, ideographic). With the help of these tools we will trace a connection between the basic ideas of Paul Ricoeur and modern trends of western historical epistemology.

\section{Results and discussion}

At the heart of the historian's craft, at a fundamental methodological nature there is an attempt to explain, appealing to objectivity. In this respect, Ricoeur does not share the bitterness of "Annales" against their predecessors of «methodical school»: in history, "it is the exact definition of objectivity: the methodical work activity", i.e. the art of documentary criticism, developed in the guide written by Seignobos and Langlois. On the contrary, works of Michelet selected by the tradition of "Annales" as a precursor have another analytical ability from the point of view of Ricoeur: to disunite the past in terms of understanding (hermeneutic), causal relations, logical deduction, emanating from the theory. "Understanding ... in this respect is not the opposite of the explanation, in fact, it is its addition and compensation" [3]. Some commentators reduced repeatedly the position of Ricoeur to pure hermeneutics, 
and to avoid errors in his last work Ricoeur tried to articulate very clearly his vision of history as a position of a delicate balance between hermeneutics and scientism [4].

An incompleteness of historical objectivity is necessarily supplemented with the subjectivity of historian on many levels: in the selection of the object of study, in the application of interpretation schemes, in the way to segregate causal relationships. In addition, the subjectivity of the historian fits in a certain historical distance; he always attempts to translate his object into modern language, the name of notion which does not exist anymore, the notion which used to be different. In the absence of a full compliance between the object of study and language resources, he makes an effort of imagination, recreating an "another real" than his own, so that it could become clear to his contemporaries. The historical imagination is a necessary means of heuristic understanding of history, a guide to the objective results. Finally, trying to explain and understand somebody similar - the people, through the thickness of time historian meet a completely another person. This fact makes subjectivity absolutely unavoidable part of historian's craft.

Hence, objectivity and subjectivity go hand in hand in history, never reaching a complete harmony. History is always open to new interpretations and revisions, to eternal search for an uncertain meaning. But researcher's freedom is not unlimited there, because leaving the space of logical constructions, Ricoeur introduces certain ethical limits for subjectivity in the history dictated by "the contract of the truth". Historian needs to inspire his "Me- researcher" encouraging to use personal experience and knowledge for the achieving the truth and to suppress the "Me-pathetic" imposing selfish value judgments.

This is the main idea in Ricoeur's book "Memory, History, Forgetting" that explains the very difference that opposes history to "fictional" genres of writing [4]. He identifies the historiographical operation in three stages of action, having several common aspects with the thought of Michel de Certeau, but gives them a peculiar tone. [5].

In the first, "archival" phase of historical inquiry the researcher makes a break with the memory, converting historical evidence into documents and subjecting them to procedures of the sources studies internal and external critics, identifying the forgery. In contrast to the French tradition hermeneutic representatives who were the followers of Raymond Aron and they did not consider the spatial and social rooting of historian, late Ricoeur appreciated history as a specific institution of knowledge with an inherent internal logic and procedures.

According to Ricoeur the second phase establishes the goal of explaining and understanding. Unlike Dilthey, he believes these two concepts cannot be separated and, by their meaning, they overwhelm the concept of interpretation. Historian deepens the distinction of his research from the area of historical memory, mobilizing various explanatory schemas, modeling special factual series. Responding to the modern methodological discussion about history,
Ricoeur found fruitful the idea of "the scale of the game," involving different levels (from micro to macro) of research focalisation [6], to get out of the false alternative which opposes adherents of historical eventfulness, on the one hand, and researchers of "long durations ", on the other.

The third stage of the historiographical operation according to Ricoeur is an investigation on the level of historical representation. In this phase, the main problem becomes writing, the presentation of research results in the text form.

In this context Ricoeur goes beyond discursive dimension, setting a specially invented concept of «répresentance» («re-presence") against the ordinary «représentation» (representation, "re-presentation") [4]. This wordplay underlines the inherent desire for truth in historical research, because the historian forms his subject of the situations and the characters really existed previously, no matter when the historian decided to tell about them. Like any source, the historical text has a certain "place affiliation" (lieutenance), irrespective of the manipulation which the researcher intends to do. Thus, the concept of "re-presence" pays tribute to the contribution of narrative theory and the same time prevents the destruction of epistemological boundaries between fiction and history, recalling the imperative of truth, which drives always the historical discourse. Although the Anglo-Americans narrative tradition has become known in France because of Paul Ricoeur's contribution, it was he who outlined adequately the limits where the research of narratives and textual procedures gives way to study of social practices in a broad sense of the word.

Arguing and proving conclusively in "Time and Narative" that the historian is unable to free himself from the narrative form of his results presentation, Ricoeur raises not only a point of the discourse, but the point of "quadrilateral of discourse": these are the speaker, creating the event of speech; his companion, what refers to the dialogic nature of any discourse; a specific meaning, with which the discourse is loaded; and, finally, the point at issue, external to the discourse. However, the interest in the procedures of writing and the importance of the poetics of the text, "a narrative identity of history" does not capture Ricoeur's striving for objectivity, which is the principal remedy against all forms of forgery and manipulation of the past.

One of the permanent subject matters in philosopher's mind production is the idea of a history "defatalisation". Contrary to the traditional tendency for the historian to explain the events in retrospective and, as a rule, simple logic of cause and consequences, the project of the future, in fact, is always open and clear. Its formation is influenced by many random factors and a certain "horizon of expectations" on the part of the living generations. The space of experience and prospects are mutually causal, creating a perpetual "generational transmission of meaning" [7] and constructing a new understanding of historical time.

Being inside a reputable hermeneutic tradition, Ricoeur borrows from Husserl's phenomenology and conveys to the historians the concept of "intentionality", 
a historical premediation, "which provides the very continuity of the duration and retain himself in the other." Ricoeur endowed H.-G. Gadamer's "Truth and Method" with a huge heuristic potential, therefrom he borrowed the topic of the "existence-defined-by-past" or, to paraphrase Gadamer, the awareness of existence exposed to the effectiveness of history "[8]. Every moment is made up of what we experience ourselves and how the expectations of the past are implementing.

Thus, the historian must stand on the position of "critical realism" in order to create a methodology that will support the reasonable ability of history to analyze a reality external to the discourse [9].

Historical epistemology of Ricoeur is still central in discussions of the 2000-2010-s. For example, in a review of the collective monograph, edited by Jörn Rüsen "Meaning and Representation in history" [10], discussing the lessons of postmodernism, G. Iggers contests the assumption that the perception of history in the modern world can be reduced to problems of a rising historical memory. Drawing on Ricoeur's studies, the author pointed out the importance of oblivion and selectivity processes of memory [11].

The paper of A. Mouzakitis "From narrative to action: Paul Ricoeur's reflections on history" seeks to present Ricoeur' oeuvres as a kind of unity, which enriches existing representations of historicity, based on the experience of the phenomenological-hermeneutic tradition, and indicates the liberating potential, immanent for human action [12].

E. Lythgoe in the article "The Role of Imagination in Paul Ricoeur's "Memory, History. Forgetting" recognizes his contribution in the analysis of the social imaginary. Exactly the imagination is, in the author's point of view, the main link between the phenomenology of memory and history of epistemology [13].

In a close ideological liaison to the intellectual heritage of Paul Ricoeur, modern theorists experimented with the concept of "historicity" by which they mean a specific perception of continuity in each particular epoch [14]. The notion of historicity originated from the German philosophical tradition and allows to rethink the problem of the eventfulness as a movement with plenty of opportunities and without any predetermined results. The historical semantics, or the "history of concepts", inspired by other ideological successor of Gadamer Reinhardt Koselleck, stimulates the development of this research trend $[15,16]$.

Historical semantics considers the scope of human action out of usual cause-and-consequence chains; the eventful canvas becomes a principal mediator, which helps to highlight symbolic forms transmitted from one generation to another. According to Koselleck, each event is located between the "space of experience" and "horizon of expectations" inherent to living generations, as a link in the process of perpetual work upon the symbolic forms of experience. This is not enough to describe the event, as it is done in the traditional historical model; you need to identify the eventfulness "conditions of possibility". The basic foundations of the historical experience are rooted in sense-making historical notions (such as a "culture", "revolution", "industrial revolution", etc.), which have the structuring ability, but were generated themselves by a specific concrete situations. These concepts, carriers of a human experience and expectations, are an expression of "a particular connection with the language from which they affect every situation and with the events in which they appear» [16]. Despite the apparent, historical concepts are not confined to the field of pure rhetoric and use not as a simple tool of classification. They are inscribed in the space of an experience in which they were born, they have become part of the language, and gradually have lost their sense, gathering a variety of semantic nuances. Koselleck as Ricoeur, does not confirm a full fusion of history and language, noting that the historical processes are not limited to their discursive dimension: "The history never coincide completely with the way by which the language captures it and articulates the experience» [16].

A. Schinkel, developing the ideas of P. Ricoeur and R. Koselleck, marks that they use a quite unclarified categories of "experience" and "expectations". As the result, the metahistorical and historical significance of these notions are confused. Besides, a continuous accidence of history, disposed to statistical calculation does not receive a due cognizance. In addition to the categories of experience and expectations, the author suggests to introduce a third category, the category of imagination as an intermediate base between the first two [17].

S.-Ch. Choi in the article "Time and History": Koselleck an Ricoeur" [18] compares the two models of temporality: " Koselleck's "modern time" and Ricoeur's "narrative time". If Kozelek's concept, starting with the history of the French Revolution acquired a modern, diachronic and a vertical dimension, charged of the progress ideology, Ricoeur, on the contrary, defends the model of historical time as a "story time" filling the gap between the subjective sense of human time and objective scale of cosmic one. Thud, that narrative, synchronic and horizontal form of "story time" allows to understand the temporal structure of human being.

Continuing to develop the theme of time, M. Blum in the paper "Phenomenological Time, Historical Time and The Writing of History" [19] argues with Paul Ricoeur's "narrative concept of time" and proves that the perception of time is based on a specific grammatical foundation which exists in the pre-reflective level. Building a grammatical analysis on Noel Chomsky' reflections, the author shows two alternative historical logic, expressed in the writings of English historians of the late Middle Ages and early modern period. E. Runia, in extension to the Ricoeur's idea of a non-discursive history dimension, opposes a nonverbal "presence" of the past in the present to the total representationalism of postmodern epoch. The presence of the past can be perceived not by the conscious effort of the historian or by a clear metaphor of the text, but by its attendence in that "history and text contain, despite the intentions of the historian" [20].

\section{Conclusion}


Thus, without rejecting neither the debt of memory - the debt "to establish justice through the memory, both in relation to the other, and to themselves," nor the intention of truth, Paul Ricoeur places the history and the memory in continuous interaction. The history can and must contribute to the transformation of "unfortunate" memory, loaded with neuroticism and pathologies, into "calm" and pacified one. Operations with memory are courses of a social action for a historian, his basic civic engagement. Memory, on the other hand, allows a historian to transcend a purely retrospective vision of the past and conceive the past as "present, that has already been" promoting a "defatalisation" of history.

Paul Ricoeur' oeuvres assemble in a single focus all the problems of modern historical knowledge, creating a dynamic balance of the basic notions, irriplacable for the historical perception and analysis. For him it was important not only a basic conventions of historical perception and writing, but also their ethical and sociopsychological impact on real human life/

An intellectual dialogue of contemporary historians with a philosopher Paul Ricoeur always promises many unexplored possibilities.

\section{Acknowledgment}

The Author would like to express gratitude to the Russian Humanitarian Science Foundation for the financial support of the presented study, the project 15 01-00427a «Modern historical epistemology and research paradigms of Western historiography in 20002015s».

\section{References}

1. A. Prost, Le Déb., 103, (1999)

2. J. Rancièr, Les Noms de l'histoire (P., Seuil, 1992)

3. P. Ricoeur, Histoire et Verité (Seuil, 1995)

4. P. Ricoeur, La Mémoire, L'Histoire, L'Oubl., P., Seuil, 675. English version: Memory, History, Forgetting (Univ. Chic. Press, Chicago-London, 2004)

5. F. Dosse, Paul Ricoeur et Michel de

Certeau : L'histoire : entre le dire et le faire,

(P., L'Hermé, 2006)

6. J. Revel (ed.), Jeux d'echelles. La micro-analyse à l'expérience (Seuil, 1996)

7. P. Ricoeur, Temps et récit., 3 t. (Seuil, 1983-1985)

8. H.G. Gadamer, Truth and Method (N.-Y., Cros., 1989)

9. Ch. Delacroix, F. Dosse, P.Garcia, Les courants historiques en France (P., A. Colin, 1998)

10. J. Rüsen (ed.), Meaning and Representation in History (N.Y.-Oxf., Berg. Books, 2006)

11. G. Iggers, Hist. and Theory, 48, 1 (2009)

12. A. Mouzakitis, Rethink. Hist., 19, 3 (2015)

13. E. Lythgoe, Dianoia, 59, 73 (2014)

14. F. Hartog, Régimes d'historicité. Présentisme et expériences du temps (P., Seuil, 2003)

15. R. Koselleck, L'expérience de l'histoire (P., Éd. l'EHESS, 1997)
16. R. Koselleck, Le Futur passé: contibution à la sémantique des temps historiques (P., Éd. l'EHESS, 1990)

17. A. Schinkel, Imagination as a category of history: an essay concerning Koselleck's concepts of Erfahrungsraum and Erwartungshorisont, Hist. and Theory, 44 (1), $42-54$ (2005)

18. S.-Ch. Choi, "Time and History": Koselleck an Ricoeur, Kor. Journ. of Hist. of Hist., 32, 423-453 (2015)

19. Blum M. Phenomenological Time, Historical Time and The Writing of History, Journ. of the Philos. of Hist., 8(1), 39-77 (2014)

E. Runia, Presence, Hist. and Theory, 45(1), 1-29 (2006) 